DAL RI, Luciene; BENARRÓS, Myriam. Da constituição imperial ao esboço: a formação do direito brasileiro e o conceito de pessoa. Revista Eletrônica Direito e Política, Programa de Pós-Graduação Stricto Sensu em Ciência Jurídica da UNIVALI, Itajaí, v.16, n.3, 30 quadrimestre de 2021. Disponível em: www.univali.br/direitoepolitica - ISSN 1980-7791.

\title{
DA CONSTITUIÇÃO IMPERIAL AO ESBOÇO: A FORMAÇÃO DO DIREITO BRASILEIRO E O CONCEITO DE PESSOA
}

\author{
FROM THE IMPERIAL CONSTITUTION TO THE ESBOÇO: THE FORMATION OF \\ BRAZILIAN LAW AND THE CONCEPT OF PERSON
}

Luciene Dal $\mathbf{R i}^{\mathbf{1}}$

Myriam Benarrós ${ }^{2}$

\section{RESUMO}

A história do direito brasileiro perpassa a constituição imperial e o seu primeiro processo de codificação em direito criminal e em direito civil. O processo codificatório civil brasileiro, por meio da contribuição de Teixeira de Freitas, reflete fundamentos em direito romano e a influência pandetística, principalmente por meio dos escritos de Savigny, desdobrando-se no desenvolvimento de conceitos basilares do ordenamento jurídico, como capacidade jurídica, sujeito de direito e pessoa. Por meio do método indutivo, bem como da análise de fontes empíricas, da revisão bibliográfica e principalmente da comparação entre as obras dos dois autores, observa-se similaridades e discordâncias nas suas concepções, permitindo delinear eixos de influência e bases de inovação no trabalho do jurista brasileiro. Por meio da pesquisa, denota-se que a influência do autor alemão é aceita naquilo em que corresponde ao resultado do método usado por Teixeira de Freitas.

PALAVRAS-CHAVE: Codificação; Teixeira de Freitas; Savigny; Esboço; Pessoa.

\footnotetext{
${ }^{1}$ Doutora em Direito pela Università degli Studi di Roma - La Sapienza; Mestre em Estudos Medievais pela Pontificia Università Antonianum. Professora no Programa de Mestrado e Doutorado em Ciência Jurídica da Universidade do Vale do Itajaí (UNIVALI) e na graduação em Direito do Centro Universitário Católica de Santa Catarina. E-mail: luciene.dalri@univali.br. O presente artigo se insere nas atividades de pesquisa do Programa de Mestrado e Doutorado em Ciência Jurídica, UNIVALI, em específico na linha de pesquisa em Constitucionalismo e Produção do Direito e no grupo de pesquisa em Estado, Constitucionalismo e Produção de Direito.

${ }^{2}$ Doutora em Direito Civil e Mestre em Direito Romano pela Universidade de São Paulo. Especialista em Direito Romano e Direito Informático pela Universidade de Roma 'La Sapienza'. Professora de Direito Civil e História do Direito no Centro Universitário Ceuni-Fametro (Manaus-AM). Pesquisadora do Grupo CNPq-GP-TCTCLAE-Teoria Crítica e Teorias Críticas Latino-Americanas e Educação. E-mail: myrian.clementoni@fametro.edu.br
} 
DAL RI, Luciene; BENARRÓS, Myriam. Da constituição imperial ao esboço: a formação do direito brasileiro e o conceito de pessoa. Revista Eletrônica Direito e Política, Programa de Pós-Graduação Stricto Sensu em Ciência Jurídica da UNIVALI, Itajaí, v.16, n.3, 30 quadrimestre de 2021. Disponível em: www.univali.br/direitoepolitica - ISSN 1980-7791.

\section{ABSTRACT}

The history of Brazilian law permeates the imperial constitution and its first codification process in criminal law and civil law. Through the contribution of Teixeira de Freitas, the Brazilian civil codification process reflects foundations in Roman law and the pandetistic influence, mainly through Savigny's writings, unfolding in the development of basic concepts of the legal system, such as legal capacity, subject of law and person. Through the inductive method, as well as the analysis of empirical sources, the literature review and especially the comparison between the works of the two authors, it is observed similarities and disagreements in their conceptions, allowing to outline axes of influence and bases of innovation in the work of the Brazilian jurist. Through the research, it is shown that the influence of the German author is accepted in that corresponds to the result of the method used by Teixeira de Freitas.

KEYWORDS: Codification; Teixeira de Freitas; Savigny; Esboço; Person.

\section{INTRODUÇÃO}

A história do direito brasileiro é marcada no século XIX pela independência do Brasil e o início da sua produção legislativa. A organização de uma constituição nacional com a previsão de separação de poderes estatais e de direito individuais corresponde aos movimentos constitucionalistas da época, com fortalecimento da esfera de liberdades do cidadão.

No rol de direitos individuais dispostos no texto constitucional está a organização da codificação civil e criminal, com fundamento nas sólidas bases da Justiça, e Equidade. A formação da codificação brasileira em base ao emaranhado de normas sobrepostas encontra como parâmetro os trabalhos europeus de codificação.

O contexto de codificação europeu é permeado por noções e conceitos jurídicos romanos e modernos que são replicados e muitas vezes reinterpretados na organização legislativa latino-americana. Nos trabalhos para a organização da codificação civil brasileira, tal fato é observado por meio da influência dos escritos de Savigny sobre os civilistas brasileiros, desdobrando-se no desenvolvimento de conceitos basilares do ordenamento jurídico, como capacidade jurídica, sujeito de direito e pessoa. 
DAL RI, Luciene; BENARRÓS, Myriam. Da constituição imperial ao esboço: a formação do direito brasileiro e o conceito de pessoa. Revista Eletrônica Direito e Política, Programa de Pós-Graduação Stricto Sensu em Ciência Jurídica da UNIVALI, Itajaí, v.16, n.3, 30 quadrimestre de 2021. Disponível em: www.univali.br/direitoepolitica - ISSN 1980-7791.

Os escritos de Savigny são objeto de pesquisa e reinterpretação, em base às fontes do direito romano, por Augusto Teixeira de Freitas, no desenvolvimento dos trabalhos da Consolidação das Leis Civis e do Esboço do Código Civil brasileiro.

A importância do tema, bem como as continuidades e descontinuidades dos elementos e noções apresentados por Savigny e Teixeira de Freitas, permitem questionar em que medida podemos atribuir à influência do jurista alemão à delineação de conceitos jurídicos, como de capacidade jurídica e de pessoa, nos escritos de Teixeira de Freitas.

Partindo do método indutivo, da análise de fontes empíricas e da revisão bibliográfica da doutrina, observa-se a clara valorização do trabalho de Savigny, diante das reinterpretações apresentadas por Teixeira de Freitas. Por meio da comparação entre as obras dos dois autores, observa-se as similaridades e discordâncias nas concepções dos autores, permitindo delinear eixos de influência e bases de inovação no trabalho do jurista brasileiro.

\section{O PANORAMA JURÍDICO NACIONAL E O IDEAL DE CODIFICAÇÃo}

O século XIX inicia-se com o Brasil como vice-reino de Portugal, sendo elevado ao status de reino associado somente no ano de $1815^{3}$, mantendo a aplicação da legislação portuguesa e ampliando o panorama normativo por meio das normas emanadas em solo brasileiro. ${ }^{4}$ Com a independência, ocorre muito lentamente a mudança do panorama normativo.

\footnotetext{
${ }^{3}$ O reconhecimento do Brasil como reino associado à Portugal ocorre por meio da Carta de Lei de 16 de dezembro de 1815 e é complementada pela Carta de 13 maio de 1816.

4 Sobre o assunto ver a coleção "Código Brasiliense": uma colheita de legislação portuguesa aplicada ao Brasil-Reino, organizada e publicada, por ordem de Dom VI João, desde 1808. A legislação joanina, no Brasil, é em grande parte de direito público, sem para tanto mudar efetivamente os instrumentos de governo. Em relação ao direito privado, aplicava-se as Ordenações Filipinas. Ver: SEELAENDER, Airton L.C.L. A policia e o Rei-Legislador: Notas sobre Algumas Tendências da legislação Portuguesa no Antigo Regime. In BITTAR, Eduardo C.B. (Org.) Historia do direito brasileiro. São Paulo: Atlas, p. 97.
} 
DAL RI, Luciene; BENARRÓS, Myriam. Da constituição imperial ao esboço: a formação do direito brasileiro e o conceito de pessoa. Revista Eletrônica Direito e Política, Programa de Pós-Graduação Stricto Sensu em Ciência Jurídica da UNIVALI, Itajaí, v.16, n.3, 30 quadrimestre de 2021. Disponível em: www.univali.br/direitoepolitica - ISSN 1980-7791.

O contexto nacional correspondia àquele apresentado pelos demais países da América Latina, onde o processo de independência política acentuou a insegurança jurídica. O conjunto de leis que regiam o direito privado brasileiro apresentava-se como um emaranhado de sobreposições que gerava incerteza em relação ao direito a ser aplicado e ensejava a produção legislativa, alimentando o ideal de codificação. 5

A Assembleia Geral Constituinte e Legislativa do Império então decretou, e D. Pedro I mandou executar, a lei de 20 de outubro de 1823 que em seu artigo 1 determinava a vigência no Brasil das Ordenações Filipinas, Leis, Decretos, Regimentos, Alvarás e Resoluções de Portugal, pelos quais o Brasil tinha se governado até o dia 25 de abril de 1821 e todos os atos legislativos promulgados desta data em diante por D. Pedro I "enquanto se não organizar um Código ou não forem especialmente alteradas". ${ }^{6}$

O direito civil português disciplinado especialmente no livro IV da Ordenações Filipinas (1603), incompleta em muitos pontos e sem nenhuma sistematização. Assim sendo, frequentemente, punha-se o problema das lacunas, ou seja, o direito a ser aplicado subsidiariamente. ${ }^{7}$

\footnotetext{
${ }^{5}$ A "crise do direito" foi a motivação das codificações européias, que a América Latina fez própria diante do quadro legislativo confuso."La conexión íntima de la crisis del derecho común, y su consiguiente crítica, con la codificación, cual remédio técnico para aquélla, a que nos acabamos de referir, puede servir para explicar, pues, la penetración de la idea codificadora, e incluso para estimar que esta recibió en América un impulso autónomo, en la medida en que también ahí, como se vio en su lugar, la crítica obedecía a una realidad sentida como propia. Tenía que resultar natural que ante el sentimiento de esta crisis surgiera en forma espontánea la concepción de conducir la pluralidad y heterogeneidad del derecho vigente a unidad, manifestada en códigos abarcadores, independientemente de la forma concreta que ellos asumieran". GUZMAN BRITO, Alejandro. Historia de la codificación civil en Iberoamérica. Santiago: Editorial Jurídica, 2006, p. 147. PETRONIO, Ugo. La Lotta per la codificazione. Torino: Giappichelli, 2002, p. 105.

${ }^{6}$ A formação do Direito Privado Brasileiro, segundo Cunha Lobo, teria iniciado com a citada lei de 20 de outubro de 1823, por ter sido o primeiro ato legislativo sobre tal matéria, oriundo do voto expresso dos representantes da nação independente. LOBO, Abelardo Saraiva da Cunha. Curso de Direito Romano. Brasília: Edições do Senado Federal, vol. 78, 2006, p. 579-580. Quanto à importância do direito português na formação do direito brasileiro ver SANTOS JUSTO, António. A influência do direito português na formação do direito brasileiro. In Revista Jurídica da FA7, Fortaleza, vol. 1, no 1 (jan./dez.) 2004, p. 197 ss.

7 Conforme ensina M. J. de Almeida Costa, entende-se por direito subsidiário um sistema de normas jurídicas chamado a colmatar as lacunas de outro sistema, portanto, o direito subsidiário está ligado ao problema das lacunas e ao das fontes de direito. COSTA, Mário Júlio de Almeida. História do Direito Português. Coimbra: Almedina, 2012, p. 341-350.
} 
DAL RI, Luciene; BENARRÓS, Myriam. Da constituição imperial ao esboço: a formação do direito brasileiro e o conceito de pessoa. Revista Eletrônica Direito e Política, Programa de Pós-Graduação Stricto Sensu em Ciência Jurídica da UNIVALI, Itajaí, v.16, n.3, 30 quadrimestre de 2021. Disponível em: www.univali.br/direitoepolitica - ISSN 1980-7791.

Nas Ordenações Afonsinas (1446-1447), primeiras ordenações portuguesas, encontra-se um quadro das fontes de direito (livro II, título 9), sendo as fontes imediatas: as leis do reino; os estilos da Corte e os costumes antigamente usados. Apenas quando não se pudesse decidir com base nelas se tornava lícito o recurso aos direitos subsidiários: o direito romano e o direito canônico.

A Lei da Boa Razão, de 18 de agosto de 1769, privilegiou o direito luso em caso de integração de lacunas, pois, proibiu o uso de texto ou de autores se houvesse preceitos das Ordenações, das leis extravagantes ou de usos do Reino, e determinou a aplicabilidade do direito romano só quando fosse conforme a boa razão, a recta ratio do jusnaturalismo. É evidente a influência da metodologia do estudo e aplicação do direito romano conhecida por usus modernus pandectarum. A metodologia se caracterizava pela abordagem ao direito romano "com os olhos postos na realidade". Os juristas tentavam individuar no Corpus Iuris Civilis as normas ainda aplicáveis (direito vivo), daquelas inaplicáveis por corresponderem às circunstâncias romanas peculiares. ${ }^{8}$

A lei promovida pelo Marquês de Pombal foi complementada pelos novos Estatutos da Universidade de Coimbra que estabeleceram critérios práticos para se individuar a conformidade do direito romano à boa razão, i.e., "apresentar-se conforme a boa razão equivalia a corresponder aos princípios do direito natural ou do direito das gentes."

\section{A CODIFICAÇÃO DO DIREITO PRIVADO NO BRASIL, APÓS A INDEPENDÊNCIA}

A Constituição Política de 1824, consagrando os princípios liberais, em seu art. 179, XVII (título 8 - Das Disposições Geraes, e Garantias dos Direitos Civis, e

8 COSTA, Mário Júlio de Almeida. História do Direito Português. Coimbra: Almedina, 2012, p. 393

9 COSTA, Mário Júlio de Almeida. História do Direito Português. Coimbra: Almedina, 2012, p. 407. 
DAL RI, Luciene; BENARRÓS, Myriam. Da constituição imperial ao esboço: a formação do direito brasileiro e o conceito de pessoa. Revista Eletrônica Direito e Política, Programa de Pós-Graduação Stricto Sensu em Ciência Jurídica da UNIVALI, Itajaí, v.16, n.3, 30 quadrimestre de 2021. Disponível em: www.univali.br/direitoepolitica - ISSN 1980-7791.

Politicos dos Cidadãos Brazileiros) previa a formação da codificação brasileira, dispondo em seu inciso XVIII, que "Organizar-se-ha quanto antes um Codigo Civil, e Criminal, fundado nas solidas bases da Justiça, e Equidade".

Seguindo o citado enunciado constitucional, promulgou-se em 1830, o Código Criminal; em 1832, o Código do Processo Criminal; em 1850, e o Código Comercial, promulgado em 25 de junho de 1850, e o Código do Processo Comercial, ou seja, os Regulamentos 737 e 738, promulgados em 25 de novembro de 1850, em cumprimento do disposto no artigo 27 do Código Comercial. ${ }^{10}$ A codificação, porém, do direito civil se apresentava bem mais difícil.11

Duas soluções teriam sido propostas, segundo Pontes de Miranda, para se harmonizar a legislação civil então vigente, esparsa, desordenada e numerosíssima ${ }^{12}$ : a) A adoção, como código, do Digesto português de Correia Telles, "o que seria a solução mais conservadora possível e não atenderia à legislação posterior à feitura do livro. Comprehende-se que o Instituto dos Advogados se opusesse, consultado, a tal medida. Seria parar e mais do que parar: retroceder."; b) A elaboração de trabalho preliminar para a codificação, a consolidação do direito vigente..$^{13}$

10 DA COSTA, Moacyr Lobo. Breve notícia histórica do direito processual civil brasileiro e de sua literatura. São Paulo: Revista dos Tribunais, 1970, p. 29-31.

${ }^{11}$ O código comercial foi aprovado em 1850. Segundo Wolkmer a realização do Código Comercial antes mesmo de uma organização da legislação acumulada em relação ao direito civil, é fruto do interesse da burguesia, que via a ordenação do comércio e da produção da riqueza como mais importante do que a proteção e garantia dos direitos civis. Sobre o assunto ver as interessantes reflexões de WOLKMER, Antonio C. Historia do direito no Brasil. Rio de Janeiro: Forense, 1999, p. 88 e 108

12 PONTES DE MIRANDA, Francisco Cavalcanti. Fontes e evolução do Direito Civil Brasileiro. Bibliotheca Scientifica Brasileira. V Collecção Economica e Juridica. Volume CCXIV. Rio de Janeiro: Pimenta de Mello, 1928, p.103-104.

${ }^{13}$ Seguindo a idéia de um processo de codificação bipartido (com a confecção primeiramente de uma consolidação e posteriormente da coidifcação): GUZMÁN BRITO, Alejandro. Codificación y consolidación: una comparación entre el pensamiento de A. Bello y el pensamiento de Teixeira de Freitas. In SCHIPANI. Sandro (Org.). Augusto Teixeira de Freitas e il diritto latinoamericano. Collana di studi giuridici latinoamericani "Roma e America", I. Padova: Cedam, 1988, p. 256. Sobre os diferentes contextos para a realização da consolidação ver: PECORELLA, Corrado. Consolidazione e codificazione in una esperienza brasiliana. In SCHIPANI. Sandro (Org.). Augusto Teixeira de Freitas e il diritto latinoamericano. Collana di studi giuridici latinoamericani "Roma e America", I. Padova: Cedam, 1988, p. 222 ss. A teoria de processo bipartido apresentada no Brasil e na América Latina também é identificada por Mario Viora sobre consolidações e codificações na Itália. Esse autor entende a consolidação como uma coleta de legislação pré-existente e ao mesmo tempo uma fase 
DAL RI, Luciene; BENARRÓS, Myriam. Da constituição imperial ao esboço: a formação do direito brasileiro e o conceito de pessoa. Revista Eletrônica Direito e Política, Programa de Pós-Graduação Stricto Sensu em Ciência Jurídica da UNIVALI, Itajaí, v.16, n.3, 30 quadrimestre de 2021. Disponível em: www.univali.br/direitoepolitica - ISSN 1980-7791.

As propostas enquadram-se nas duas grandes correntes presentes no quadro das codificações latino-americanas, em que a primeira recebeu uma acentuada influência europeia, com a adoção dos Códigos Civis da França (1804) ${ }^{14}$, Itália $(1865)^{15}$ e Espanha (1889) ${ }^{16}$; e a segunda teve uma influência mais tênue, produzindo codificação própria e abrindo espaço para a introdução de novos elementos tipicamente latino-americanos. ${ }^{17}$

No Brasil prevaleceu a segunda solução, desenvolvendo-se lentamente uma codificação própria. Nota-se nesse sentido alguns movimentos a partir de 1830 para a sistematização do direito civil brasileiro, como o estudo realizado por Carvalho Moreira, posteriormente Barão de Penedo, em 1845 "Da revisão geral e codificação das leis civis e de processo do Brasil" demonstrando o complexo quadro normativo e as dificuldades do nosso direito civil.

Em paralelo aos problemas normativos que envolviam o direito civil brasileiro, nota-se o apego de Dom Pedro II ao que se pode chamar de "ideal de codificação".18 A assimilação do processo de codificação, não se limita a uma forma de exposição normativa conforme à europeia, mas exige a instauração e a manutenção de instrumentos jurídicos que se identifiquem com aquele. Nota-se

do processo de formação dos códigos. VIORA, Mario E. Consolidazione e codificazione: contributo alla storia della codificazione. $3^{\circ}$ ed. Torino: Giappichelli, 1967 . Com reservas e críticas em relação à teoria de Viora: SCHIPANI, Sandro. La codificazione del diritto romano comune. Torino: Giappichelli, 1999, p. 320, nota 5; PETRONIO, Ugo. La lotta per la codificazione. Torino: Giappichelli, 2002, p. 92 ss.; esp. p. 111, 127 e 130.

14 O processo de adoção direta de um Código implica, na sua tradução, análise e modificação por uma comissão do país "receptor". Nesse sentido, o Haiti, a Bolívia, a Costa Rica e a República Dominicana adotaram (com modificações) o Code Civil des Français (1804), posteriormente conhecido como Code Civil de Napoléon.

15 A Venezuela adotou (com modificações) o Codice Civile del Regno d'Italia (1865), que seguia o modelo francês.

16 Cuba, Porto Rico e Honduras adotaram (com modificações) o Código Civil Español (1889). Os trabalhos para a realização do código espanhol têm como base o Proyecto de Código Civil Español de Florencio Garcia Goyena (1851). O "proyecto" não foi aprovado na Espanha, mas foi adotado (com modificações) na Venezuela (1867) e influenciou o Código Civil del Imperio Mexicano (1869) e o Código del Distrito Federal y Territorio de la Baja California (1870).

17 Dentre os países que produziram codificação própria está o Peru, o Chile, a Venezuela, o México, a Argentina e o Brasil. Ver: ESPITIA GARZÓN, Fabio. Historia del Derecho Romano. $2^{\circ}$ ed. Bogotá: Universidad Externado de Colombia, 2006, p. 624 ss.

18 Não se tratava apenas de uma mentalidade eurocêntrica, mas da consciência de uma realidade comercial, de importação e exportação, que encontrava nos países europeus seu principal interlocutor. 
DAL RI, Luciene; BENARRÓS, Myriam. Da constituição imperial ao esboço: a formação do direito brasileiro e o conceito de pessoa. Revista Eletrônica Direito e Política, Programa de Pós-Graduação Stricto Sensu em Ciência Jurídica da UNIVALI, Itajaí, v.16, n.3, 30 quadrimestre de 2021. Disponível em: www.univali.br/direitoepolitica - ISSN 1980-7791.

assim um processo em espiral onde não ocorre um rompimento traumático com o sistema jurídico europeu, mas a sua adequação à realidade brasileira e latinoamericana.

O Governo imperial, em 15 de fevereiro de 1855, por indicação de José Tomás Nabuco de Araújo, Ministro da Justiça e senador do Império, contratou Teixeira de Freitas para elaborar a Consolidação das Leis Civis, classificando as leis vigentes, portuguesas e brasileiras, por ordem cronológica e segundo a divisão em públicas e privadas. ${ }^{19}$

\section{AUGUSTO TEIXEIRA DE FREITAS E O DIREITO ROMANO}

Teixeira de Freitas era um profundo conhecedor do direito romano, a leitura e análise de suas obras comprovam uma sólida formação romanística. Era, contudo, um autodidata, pois, como observa Moreira Alves, não foi no curso de direito de Olinda ou de São Paulo que Teixeira de Freitas estudou o direito romano:

[...] a lei que fundou, em 11 de agosto de 1827, os Cursos Jurídicos não colocou no currículo, o ensino dessa disciplina [Instituições de Direito Romano]. Somente em 1854 é que se instalou a cadeira de Institutas de Direito Romano, criada pelo Decreto Legislativo de 16 de agosto de 1851.

Não foi, portanto, nos bancos da Academia de Direito de São Paulo ou da Escola de Olinda, onde veio a formar-se em 1837, que Teixeira de Freitas estudou direito romano. ${ }^{20}$

${ }^{19}$ Augusto Teixeira de Freitas viveu de 1816 a 1883. Formou-se em Direito em 1837, na Academia de Ciências Sociais e Jurídicas de Olinda; em 1843, transferiu-se para o Rio de Janeiro, onde, em 1843 fundou o Instituto dos Advogados Brasileiros, do qual, quatorze anos depois, viria a ser presidente.

20 MOREIRA ALVES, José Carlos. A formação romanística de Teixeira de Freitas e seu espírito inovador. In: SCHIPANI, Sandro (Org.). Augusto Teixeira de Freitas e il Diritto Latinoamericano. Collana di studi giuridici latinoamericani "Roma e America", I. Padova: Cedam, 1988 , p. 19. 
DAL RI, Luciene; BENARRÓS, Myriam. Da constituição imperial ao esboço: a formação do direito brasileiro e o conceito de pessoa. Revista Eletrônica Direito e Política, Programa de Pós-Graduação Stricto Sensu em Ciência Jurídica da UNIVALI, Itajaí, v.16, n.3, 30 quadrimestre de 2021. Disponível em: www.univali.br/direitoepolitica - ISSN 1980-7791.

No embate travado com Caetano Alberto Soares, no Instituto dos Advogados Brasileiros, quanto ao status dos filhos de escrava que, em testamento, havia sido liberta, mas com cláusula de servir a um herdeiro ou legatário enquanto vivesse, Teixeira de Freitas, fundamentando o seu parecer no direito romano, direito aplicado no Brasil subsidiariamente, afirma serem esses escravos. A divergência entre os dois juristas teve como desfecho a renúncia de Teixeira de Freitas à presidência do Instituto. Na carta de renúncia, de 22 de outubro de 1857, encontramos a sua profissão de fé como romanista:

E demais, não podeis fazer maior honra, do que chamandome romanista. Nas leis e doutrinas do direito romano está depositada toda a filosofia do direito $[\ldots]^{21}$

A importância do direito romano na construção sistêmica do jurisconsulto baiano é evidenciada por Miguel Reale:

[...] o fator que assegura a unidade sistemática do pensamento jurídico de Teixeira de Freitas é o Direito Romano, como se depreende desta sua incisiva afirmação: «nas leis e na doutrina do Direito Romano está depositada toda a Filosofia do Direito». ${ }^{22}$

Para Reale, no espírito de Teixeira de Freitas casam-se elementos da Escola Histórica e do Direito Natural, exigência ideal da razão, em função da realidade, numa compreensão individual e social do direito, como resulta da lição que acolhe de Ahrens sobre a propriedade, concebida como composição de dois elementos, um voltado para o indivíduo e outro voltado para a sociedade, não devendo um ser absorvido pelo outro ${ }^{23}$, relevando ainda "serem ambos reflexos das relações

21 MOREIRA ALVES, José Carlos. A formação romanística de Teixeira de Freitas e seu espírito inovador. In: Sandro SCHIPANI (Org.). Augusto Teixeira de Freitas e il Diritto Latinoamericano. Collana di studi giuridici latinoamericani "Roma e America", I. Padova: Cedam, 1988 , p. 20

22 REALE, Miguel. Humanismo e Realismo Jurídicos de Teixeira de Freitas. In: SCHIPANI, Sandro (Org.). Augusto Teixeira de Freitas e il Diritto Latinoamericano. Collana di studi giuridici latinoamericani "Roma e America", I. Padova: Cedam, 1988, p. 42.

${ }^{23}$ AHRENS, Heinrich. Cours de droit naturel. 8 ed. Leipzig: F.A. Brockhaus, 1892, p. 154. Cf. TEIXEIRA DE FREITAS, Augusto. Consolidação das Leis Civis. $3^{\circ}$ ed. (edição fac-simile). Brasília: Senado Federal, 2003. Ver Introdução, p. CXCII, n. 353: "Do mesmo modo que o indivíduo não deve ser absorvido pela sociedade, também o direito individual de propriedade não se perde no direito individual". 
DAL RI, Luciene; BENARRÓS, Myriam. Da constituição imperial ao esboço: a formação do direito brasileiro e o conceito de pessoa. Revista Eletrônica Direito e Política, Programa de Pós-Graduação Stricto Sensu em Ciência Jurídica da UNIVALI, Itajaí, v.16, n.3, 30 quadrimestre de 2021. Disponível em: www.univali.br/direitoepolitica - ISSN 1980-7791.

orgânicas que devem existir entre o indivíduo e a sociedade, entre o homem e a humanidade"24:

Não nego certo ecletismo na posição de Teixeira de Freitas, o qual, no entanto, preserva a unidade de suas ideias, dada a sua formação romanista. É a constante referência ao Direito Romano, como uma espécie de pedra de toque ou de aferição dos diagnósticos jurídicos, que assegura unidade às concepções de Teixeira de Freitas, o qual alia poderosa capacidade inovadora a múltiplos valores tradicionais. ${ }^{25}$

Teixeira de Freitas, como os jurisconsultos romanos, tinha plena consciência de que hominum causa omne ius constitutum sit (Hermogenianus, D. 1.5.2.) ${ }^{26}$, tendo o jurista a missão de, com paciência e olhos no futuro, adaptar o ius à realidade mutável dos homens.

\section{A OBRA CONSOLIDATÓRIA E A PROPOSTA DE CODIFICAÇÃO DO DIREITO PRIVADO BRASILEIRO}

Com espírito livre e não condicionado por quaisquer doutrinas ou opiniões, ele estabelece o método a ser usado na ingente obra comissionada pelo Governo Imperial, a Consolidação das Leis Civis. A obra compõe-se de duas partes:

1) A Introdução, parte científica que diz respeito aos limites do Direito Civil:

Para achar, porém, os limites do Direito Civil e a norma da exposição das matérias que lhe pertencem, recorremos a estudos de outra natureza, consultamos os monumentos legislativos, revimos e meditamos as tradições da ciência, e com toda liberdade de espírito procuramos essa unidade

\footnotetext{
24 REALE, Miguel. Humanismo e Realismo Jurídicos de Teixeira de Freitas. In SCHIPANI, Sandro (Org.). Augusto Teixeira de Freitas e il Diritto Latinoamericano. Collana di studi giuridici latinoamericani "Roma e America", I. Padova: Cedam, 1988, p. 43.

25 REALE, Miguel. Humanismo e Realismo Jurídicos de Teixeira de Freitas. In SCHIPANI, Sandro (Org.). Augusto Teixeira de Freitas e il Diritto Latinoamericano. Collana di studi giuridici latinoamericani "Roma e America", I. Padova: Cedam, 1988, p. 43.

26 TEIXEIRA DE FREITAS, Augusto. Consolidação das Leis Civis, $3^{a}$ ed. (edição fac-simile). Brasília, Senado Federal, 2003, p. CXXI, 205. Para a tradução de D. 1.5.2 ver Digesto de Justiniano. Liber Primus: Introdução ao direito romano. Tradução de Hélcio Maciel França MADEIRA. $2^{\circ}$ ed. São Paulo: Editora Revista dos Tribunais, 2000, p. 55.
} 
DAL RI, Luciene; BENARRÓS, Myriam. Da constituição imperial ao esboço: a formação do direito brasileiro e o conceito de pessoa. Revista Eletrônica Direito e Política, Programa de Pós-Graduação Stricto Sensu em Ciência Jurídica da UNIVALI, Itajaí, v.16, n.3, 30 quadrimestre de 2021. Disponível em: www.univali.br/direitoepolitica - ISSN 1980-7791.

superior, que concentra verdades isoladas, penetra as mais recônditas relações, e dá esperanças de um trabalho consciencioso. ${ }^{27}$

2) A parte prática, a consolidação do direito vigente, consiste nas palavras do jurisconsulto baiano na "consolidação em mostrar o ultimo estado da Legislação":

A parte prática, e, por assim dizer, material do trabalho, terá em si mesma a prova de sua boa ou infeliz execução, já quanto às disposições adotadas e substanciadas, já quanto à fidelidade e exatidão do transunto, já quanto às qualidades do estilo. Os legistas limitar-se-ão a comparar o texto de cada um dos artigos com a lei ou leis que o abonam em suas respectivas notas. Os jurisperitos irão mais longe, e nessas mesmas notas acharão fecundos traços, proposições susceptíveis dos mais ricos desenvolvimentos. A natureza do trabalho não consentia demonstrações. ${ }^{28}$

É na Introdução que Teixeira de Freitas indica o método adotado para "achar os limites do direito Civil e a norma das matérias que Ihe pertencem":

Examinar as leis em seus próprios textos sem influência de alheias opiniões, comparar atentamente as leis novas com as antigas, medir com precisão o alcance e as consequências de umas e outras; eis o laborioso processo, que empregado temos para conhecer a substancia viva da legislação. ${ }^{29}$

O jurista do Império na Introdução à Consolidação distingue três pontos programáticos para o seu trabalho, partindo de uma consideração de caráter concreto, ou seja, se a Consolidação tem que ser o 'extracto fiel' da 'legislação civil' no seu último estágio. O método para realizar esse objetivo é examinar as leis segundo os seus próprios textos sem a influência de opiniões alheias; comparar atentamente as novas com as antigas; medir com precisão o alcance e as consequências de umas e outras ${ }^{30}$. Os textos legislativos são a base e devem

\footnotetext{
27 TEIXEIRA DE fREITAS, Augusto. Consolidação das Leis Civis, $3^{a}$ ed. (edição fac-simile). Brasília, Senado Federal, 2003, pp. XXXVI-XXXVII.

28 TEIXEIRA DE FREITAS, Augusto. Consolidação das Leis Civis, $3^{a}$ ed. (edição fac-simile). Brasília, Senado Federal, 2003, p. XXXVII; ver também p. XXXI; p. XXXVIII/XXXIX.

29 TEIXEIRA DE FREITAS, Augusto. Consolidação das Leis Civis, $3^{a}$ ed. (edição fac-simile). Brasília, Senado Federal, 2003, p. XXXVI.

${ }^{30}$ TEIXEIRA DE FREITAS, Augusto. Consolidação das Leis Civis, $3^{a}$ ed. (edição fac-simile). Brasília, Senado Federal, 2003, p. XXXVI.
} 
DAL RI, Luciene; BENARRÓS, Myriam. Da constituição imperial ao esboço: a formação do direito brasileiro e o conceito de pessoa. Revista Eletrônica Direito e Política, Programa de Pós-Graduação Stricto Sensu em Ciência Jurídica da UNIVALI, Itajaí, v.16, n.3, 30 quadrimestre de 2021. Disponível em: www.univali.br/direitoepolitica - ISSN 1980-7791.

ser examinados sem a interferência de alheias interpretações e da praxe. Esse primeiro ponto programático não o conduz, porém, a ser prisioneiro da própria legislação, quase isolada da interpretação, ao contrário, é a conquista de um amplo espaço para a iurisprudentia do próprio jurista. O segundo ponto programático é a mensuração rigorosa das leis, do seu alcance e projeção para que se possa achar os limites do Direito Civil, para se conhecer a substância da legislação, ou seja, a definição do objeto exato do trabalho a ser efetuado, fixando-se o modo por meio do qual se possa individuar a norma de exposição das matérias, individuando-se nesta a relevância interna ao direito, seja para a determinação do alcance das normas, seja para um trabalho de simplificação, em relação aos quais as notas, a memória do caminho percorrido, constituem uma base permanente onde os jurisconsultos poderão encontrar fecundos traços, proposições susceptíveis dos mais ricos desenvolvimentos ${ }^{31}$. O terceiro ponto programático é a individuação de como executar os primeiros dois pontos programáticos: recorre-se a estudos de outra natureza; consulta-se os monumentos legislativos; revê-se e medita-se as tradições da ciência; procura-se livremente a unidade superior que concentra as verdades isoladas, que penetra as mais recônditas relações, e dá a esperança de que seja feito um trabalho consciencioso. Em suma, comparação interna ao sistema e tradição científica a ele atinente são os pilares metodológicos para uma fiel interpretação sistemático-constitutiva do Direito Civil, a partir das leis. As contribuições sedimentadas no espaço e no tempo, em lugares ou momentos longínquos, têm um valor atual para o jurista que se apropria da totalidade do sistema para extrair do seu interno, de forma crítica e construtiva, os cânones da exposição da matéria, os critérios da composição unitária desta que guiam a interpretação das normas, a seleção e a hierarquização destas na determinação dos respectivos âmbitos de atuação. O resultado da revisão crítica é a sistemática do Direito Civil elaborada na Consolidação que se caracteriza pelas divisões dicotômicas: uma Parte Geral e uma Parte Especial, a primeira dividida em pessoas e coisas, e a segunda em direitos pessoais e direitos reais. O binômio da Parte

${ }^{31}$ TEIXEIRA DE FREITAS, Augusto. Consolidação das Leis Civis, $3^{a}$ ed. (edição fac-simile). Brasília, Senado Federal, 2003, p. XXXVII. 
DAL RI, Luciene; BENARRÓS, Myriam. Da constituição imperial ao esboço: a formação do direito brasileiro e o conceito de pessoa. Revista Eletrônica Direito e Política, Programa de Pós-Graduação Stricto Sensu em Ciência Jurídica da UNIVALI, Itajaí, v.16, n.3, 30 quadrimestre de 2021. Disponível em: www.univali.br/direitoepolitica - ISSN 1980-7791.

Geral, pessoas e coisas, conserva traços do original institucional, se se prescinde da eliminação do discurso inicial sobre a justiça, sobre o direito e as suas fontes. ${ }^{32}$

Elemento de referência da ordem sistemática, profundamente, renovado, é a pessoa, e no que concerne à normativa a ela pertinente é interessante sublinhar a relevância do método, pois, este é o instrumento por meio do qual o autor opera inovações substanciais, valorizando perfis da tradição, com uma obra historicamente constitutiva do direito, por meio da ordem das normas, ele conserva a concretude da pessoa-homem. Tal fato é observado no Título I da Parte Geral que começa pelo homem em sua vida preparatória, nasciturus, venter, qui in utero est.

Para Schipani a comparação interna ao sistema e a sua tradição científica própria são os pilares metodológicos para uma fiel interpretação sistemático-constitutiva do direito civil a partir das leis. As construções doutrinárias elaboradas em lugares diversos e em momentos longínquos possuem um valor atual para o jurista que as absorve e as interioriza apropriando-se da totalidade do sistema para retirar do seu interno de maneira crítica e construtiva os cânones da exposição da matéria, os critérios para a elaboração unitária desta, critérios esses que guiam a interpretação das normas, a seleção e hierarquia dessas ao determinar-se os respectivos âmbitos de operabilidade. ${ }^{33}$

A Consolidação, na sua parte prática, também, desdobra-se em duas partes, sendo a primeira, a Parte Geral que compreende dois títulos, o primeiro "das pessoas", o segundo "das coisas"; e a segunda, a Parte Especial, em dois livros, o primeiro "dos direitos pessoais", o segundo "dos direitos reais".

Destarte, no que concerne à classificação dos direitos, o sistema que adota, após submeter a exaustiva crítica o das Institutas de Gaio e Justiniano (pessoas, coisas

32 SCHIPANI, Sandro. La codificazione del diritto romano comune. Torino: Giappichelli Editore, 2011 , p. 330-336.

33 TEIXEIRA DE FREITAS, Augusto. Consolidação das Leis Civis, $3^{a}$ ed. (edição fac-simile), Coleção História do Direito Brasileiro, Brasília, Senado Federal, 2003, p. CXXVI. Cf. SCHIPANI, Sandro. La codificazione del diritto romano comune. Torino: Giappichelli Editore, 2011, p. 331-332. 
DAL RI, Luciene; BENARRÓS, Myriam. Da constituição imperial ao esboço: a formação do direito brasileiro e o conceito de pessoa. Revista Eletrônica Direito e Política, Programa de Pós-Graduação Stricto Sensu em Ciência Jurídica da UNIVALI, Itajaí, v.16, n.3, 30 quadrimestre de 2021. Disponível em: www.univali.br/direitoepolitica - ISSN 1980-7791.

e ações) e os modernos, desde o de Leibniz até o dos romanistas alemães, é constituído por uma primeira divisão em duas grandes categorias: os direitos pessoais e os direitos reais que formam a Parte Especial. Uma Parte Geral antecede a parte especial. Pela primeira vez na legislação civil, adotava-se a sistemática alemã utilizada nas obras dos pandectistas, i.e., com uma parte geral, contendo os elementos constitutivos do direito subjetivo, e uma parte especial, constituída pelas regras referentes aos direitos subjetivos em espécie. ${ }^{34}$ Ressalta Arnold Wald:

Essa distinção já se encontrava em vários outros autores da época, como Ortolan, mas coube a Teixeira de Freitas aplicála pela primeira vez no campo legislativo, na América Latina, fazendo a distinção entre a parte geral e a parte especial da Consolidação, e antecipando-se, assim, em quarenta anos, às soluções que iriam ser adotadas pelo BGB, que entrou em vigor em $1^{\circ} \cdot 1.1900 .{ }^{35}$

É na sistemática da Consolidação que Teixeira de Freitas mostra o seu espírito inovador. Alicerçando o seu raciocínio não somente na sua sólida formação romanista, mas também no seu profundo conhecimento das doutrinas em voga, principalmente a francesa e a alemã, ele reflete minuciosamente sobre as tradições da ciência jurídica e submete as posições existentes a uma crítica construtiva, buscando uma perfeição inatingível que, de certa forma, será o óbice à realização do seu sonho maior, ser o autor do primeiro Código Civil Brasileiro.

O sistema construído por Teixeira de Freitas na Consolidação tem como fulcro de referência a ideia de pessoa. Para ele, em primeiro lugar, há o homem, pois "os direitos existem por causa das pessoas; onde não há pessoas, não pode haver questão de direito" ${ }^{36}$, segue o jurisconsulto do Império os princípios das Institutas de Justiniano: Nam parum est ius nosse, si personae, quarum causa statutum est,

34 MOREIRA ALVES, José Carlos. A formação romanística de Teixeira de Freitas e seu espírito inovador. In: Sandro SCHIPANI (Org.). Augusto Teixeira de Freitas e il Diritto Latinoamericano. Collana di studi giuridici latinoamericani "Roma e America", I. Padova: Cedam, 1988 , p. 26-27.

35 WALD, Arnold. A obra de Teixeira de Freitas e o Direito Latino-Americano. In Revista de Informação Legislativa. Brasília, a. 41 n. 163 jul/set. 2004, p. 251.

${ }^{36}$ TEIXEIRA DE FREITAS, Augusto. Consolidação das Leis Civis, $3^{a}$ ed. (edição fac-simile). Brasília, Senado Federal, 2003, p. CXLVI. 
DAL RI, Luciene; BENARRÓS, Myriam. Da constituição imperial ao esboço: a formação do direito brasileiro e o conceito de pessoa. Revista Eletrônica Direito e Política, Programa de Pós-Graduação Stricto Sensu em Ciência Jurídica da UNIVALI, Itajaí, v.16, n.3, 30 quadrimestre de 2021. Disponível em: www.univali.br/direitoepolitica - ISSN 1980-7791.

ignorentur (I. 1.2.12) - Mas primeiro tratemos das pessoas; pois, de pouco vale conhecer o direito, se se ignoram as pessoas por causa das quais foi ele estatuído. ${ }^{37}$

A Consolidação das Leis Civis realizada por Teixeira de Freitas cumpriu o seu objetivo, organizando e refletindo o conteúdo normativo pré-existente. $38 \mathrm{Em}$ 1859, logo que aprovado o texto da Consolidação das Leis Civis (1858), Nabuco de Araújo, contratou Teixeira de Freitas para então elaborar o projeto de Código Civil.

No Esboço do Código Civil, Teixeira de Freitas pôde expressar o seu espírito inovador, pois, não estava adstrito aos vínculos ínsitos à Consolidação. O plano do Esboço é um aprimoramento da sistemática da Consolidação. Na Parte Geral, acrescentou às pessoas e às coisas, os fatos, mudando, dessa forma, o posicionamento tido quando da feitura da Consolidação ${ }^{39}$. Em carta de 20 de novembro de 1866, endereçada a Martim Francisco Ribeiro de Andrada, Ministro da Justiça, o próprio Teixeira de Freitas informa que o Esboço já tinha 5.016 artigos prontos, dois mil há mais do que a maioria dos códigos conhecidos, com exceção

37 CORREIA, Alexandre; SCIASCIA, Gaetano. Manual de Direito Romano. Institutas de Gaio e de Justiniano vertidas para o português. Volume II. São Paulo: Edição Saraiva, 1951, p. 306-307. 38 Como advogado do Conselho de Estado o jurista brasileiro apresentou o plano para a consolidação das leis ao governo imperial, o qual é aprovado, celebrando o contrato que objetivava "coligir e classificar toda a legislação pátria e consolidar a civil" em 15 de fevereiro de 1855. Sobre a consolidação ver: MEIRA, Silvio. Teixeira de Freitas. 0 jurisconsulto do Imperio. Brasilia: Cegraf, 1983, p. 92 ss., esp. 111 ss. A Consolidação foi promulgada em 1855 com sua entrada em vigor em 1857, tendo grande apreço pelos juristas da época e sendo vigente durante todo o período de ausência do Código Civil.

39 Na nota ao artigo 431 do Esboço, Teixeira de Freitas justifica a nova posição: "Esta Secção $3^{a}$, que trata dos fatos, um dos elementos dos direitos regulados no Código Civil, não estava em meu primitivo plano, como se pode ver na Consolid. Das Leis Civ. Introd., pp. 106, 107 e 108 . Ali eu disse "alguns Escritores adicionam este terceiro elemento sob a denominação de fatos, fatos jurídicos, atos jurídicos, de que também tratam na parte geral das matérias do Direito Civil. Não nos conformamos com este método". Hoje, ao contrário, estou convencido de que sem este método será impossível expor com verdade a síntese das relações do Direito privado, e fugir a um defeito gravíssimo de que se ressentem todos os Códigos, com exceção ùnicamente do da Prússia. Êles têm legislado sôbre matérias de aplicação geral a quase todos os assuntos do Código Civil, do Código de Comércio e do Código do Processo, como se fôssem exclusivamente aplicáveis só aos contratos e testamentos; e com êste sistema embaraçam o exato conhecimento do Direito Privado, isolando fenômenos que são efeitos da mesma causa, e contribuindo destarte para que muitas espécies escapem à influência de seus princípios diretores.". Ver TEIXEIRA DE FREITAS, Augusto. Esboço do Código Civil. Brasília: Ministério da Justiça, Fundação Universidade de Brasília, 1983, p. 143. 
DAL RI, Luciene; BENARRÓS, Myriam. Da constituição imperial ao esboço: a formação do direito brasileiro e o conceito de pessoa. Revista Eletrônica Direito e Política, Programa de Pós-Graduação Stricto Sensu em Ciência Jurídica da UNIVALI, Itajaí, v.16, n.3, 30 quadrimestre de 2021. Disponível em: www.univali.br/direitoepolitica - ISSN 1980-7791.

do código da Prússia. ${ }^{40}$ contudo, foram publicados somente 4.908 artigos, com seus respectivos e riquíssimos comentários.

A versão final do Esboço apresenta, antes da Parte Geral, um título preliminar "Do lugar e do tempo" que estabelece os princípios concernentes ao âmbito de aplicação das normas no espaço e no tempo, explicando o codificador que tais normas são necessárias "não porque se legisle para países estrangeiros, e se possa ordenar que autoridades estrangeiras apliquem ou não as leis deste Código, ou outras leis; mas porque as leis deste Código devem sòmente ser aplicadas pelas autoridades do país às pessoas, coisas, fatos e direitos, que no território do país têm sua sede". ${ }^{41}$ Segue a Parte Geral contendo todas as disposições concernentes aos elementos das relações jurídicas: 'pessoas', 'coisas' e 'fatos'. Após, temos uma Parte Especial, em dois livros, disciplinando especificadamente as relações jurídicas dicotomicamente consideradas: 'direitos pessoais' e 'direitos reais'. Por fim, o livro IV "das disposições comuns aos direitos reais e aos direitos pessoais" que tinha sido autorizado pelo Governo por aditamento ao contrato de 10 de janeiro de 1859, já que não constava do plano da Consolidação aprovado em 4 de dezembro de 1858.

Durante os trabalhos, a publicação do Esboço ocorria em fascículos, apresentando ao lado de cada artigo um comentário com explicações para a sua correta interpretação e aplicação. ${ }^{42}$

A obra, porém, não foi terminada por Freitas, devido à sua renúncia ao projeto de código civil por divergências insuperáveis com o Governo que não aceitou o novo plano sistemático, proposto na Carta de 20 de setembro de 1867.43 Em 1872,

\footnotetext{
40 MEIRA, Silvio. Teixeira de Freitas. O jurisconsulto do Império. Rio de Janeiro: J. Olympio, 1979 , p. 363.

${ }^{41}$ TEIXEIRA DE FREITAS, Augusto. Esboço do Código Civil. Brasília: Ministério da Justiça, Fundação Universidade de Brasília, 1983, p. 1.

42 Os comentários exaustivos do jurista brasileiro ao seu trabalho são uma tentativa de evitar a interpretação errônea do texto. A tendência à evitar interpretações à letra do código é presente nas codificações de Justiniano e de Napoleão.

43 O livro IV dedicado à herança, ao concurso de credores e à prescrição não chegou a ser elaborado por Teixeira de Freitas. LOBO, Abelardo Saraiva da Cunha. Curso de Direito Romano. Brasília: Edições do Senado Federal, vol. 78, 2006, p. 593-603.
} 
DAL RI, Luciene; BENARRÓS, Myriam. Da constituição imperial ao esboço: a formação do direito brasileiro e o conceito de pessoa. Revista Eletrônica Direito e Política, Programa de Pós-Graduação Stricto Sensu em Ciência Jurídica da UNIVALI, Itajaí, v.16, n.3, 30 quadrimestre de 2021. Disponível em: www.univali.br/direitoepolitica - ISSN 1980-7791.

Duarte de Azevedo, ministro da Justiça, declarou inaceitável a proposta de Teixeira de Freitas, embora reconhecesse que tinha fundamento razoável a ideia de um Código Geral contendo matérias de direito comercial e de direito civil. Expediu-se o ofício pelo qual o contrato de 1859 estava rescindido, Teixeira de Freitas não seria o autor do primeiro Código Civil Brasileiro.

Não obstante a não continuidade do projeto de codificação de Teixeira de Freitas, ele deixou uma obra que contribuiu significativamente para a modernização do direito privado brasileiro. Ademais, a Consolidação das Leis Civis foi de fato o direito vigente até a entrada em vigor do Código de Clovis Bevilaqua em 1917, fornecendo um suporte imprescindível à prática jurídica. A obra freitiana, ainda hoje, impressiona pelo profundo conhecimento da literatura jurídica da época, em particular, foi o jurista baiano um admirador de F.C. von Savigny, e inúmeras são as referências ao pensamento do jurista alemão.

Teixeira de Freitas estudou e interpretou a obra de Savigny em uma época em que os primeiros juristas formados no Brasil começam a promover a modernização das instituições brasileiras. Muitas das soluções propostas pelo jurista do Império foram influenciadas pela leitura de Savigny "Isso se nota não apenas na utilização de expressões diretamente reconduzíveis ao léxico savignyano como, por exemplo, "relação jurídica" (Rechtsverhältnis) ou "instituição de direito" (Rechtsinstitut), mas também em passagens inteiras onde Freitas parafraseava Savigny, muitas vezes sem qualquer referência"44.

Os juristas brasileiros no primeiro quartel do século XIX leram a vasta obra de Savigny, por meio das traduções francesas disponíveis no Brasil. Neste contexto, enquadra-se Teixeira de Freitas que citou sobretudo o System na tradução de Guénou, publicada entre 1840 e 1851 em Paris, bem como o Das Recht des Besitzes na tradução de D'Audelange, publicada também em Paris em $1841 .{ }^{45}$

\footnotetext{
44 REIS, Thiago. Teixeira de Freitas leitor de Savigny. In: Interpretatio Prudentium direito romano e tradição romanista em revista. Lisboa, I, 2016, p. 214.

45 REIS, Thiago. Teixeira de Freitas leitor de Savigny. In: Interpretatio Prudentium direito romano e tradição romanista em revista. Lisboa, I, 2016, p. 213-215.
} 
DAL RI, Luciene; BENARRÓS, Myriam. Da constituição imperial ao esboço: a formação do direito brasileiro e o conceito de pessoa. Revista Eletrônica Direito e Política, Programa de Pós-Graduação Stricto Sensu em Ciência Jurídica da UNIVALI, Itajaí, v.16, n.3, 30 quadrimestre de 2021. Disponível em: www.univali.br/direitoepolitica - ISSN 1980-7791.

\section{INFLUÊNCIA E CONTRAPOSIÇÃO ÀS IDÉIAS DE SAVIGNY EM TEIXEIRA DE FREITAS}

Savigny influencia fortemente o ambiente jurídico europeu e latino-americano com os "resultados" do método pandetístico por meio da obra System des heutingen römischen Rechts. Os estudos realizados por esse "movimento metodológico" não escaparam ao observador Teixeira de Freitas, refletindo certa influência na confecção da Consolidação. ${ }^{46} \mathrm{O}$ jurista brasileiro com aprofundado conhecimento do direito romano e hodierno não recebeu passivamente as ideias e inovações de Savigny, mas as reinterpretou por meio da desconstrução intelectual de seus fundamentos. A influência exercida por Savigny não foi, portanto, decisiva em muitos pontos do Esboço, permitindo o delinear de uma concepção jurídica autônoma e a consequente transcendência às categorias de sujeito e objeto do direito. O conceito e a regulamentação em matéria de pessoa é um dos exemplos de re-interpretação e contraposição às ideias do jurista alemão, tendo como base a tradição romanística e ao Direito romano. ${ }^{47}$

\subsection{Os resultados do método de Savigny: o conceito de pessoa e a capacidade jurídica natural}

A escola histórica alemã, fundada por Savigny, impõe uma renovação no método de trabalho dos juristas alemães do século XIX, em relação à aplicação do texto das Pandectae de Justiniano, como norma vigente. ${ }^{48}$ Inicia-se assim o método de

\footnotetext{
46 Um claro exemplo da influência de Savigny constata-se no art. 40, nota 52 da Consolidação das Leis Civis, que trata da "pessôas singulares" ou "collectivas". Nesse o jurista remete à leitura de "Savigny Dir. Rom. Tom. 2० p. 237 Not".

47 "E também devo recomendar que, suposto estas minhas idéias estejam de acordo com as de Savigny, e de outros Escritores alemães, todavia não são perfeitamente semelhantes, por isso mesmo que as enuncio em toda a liberdade, e sem referência ao Direito Romano, sobre cujas noções erigira Savigny o seu sistema". TEIXEIRA DE FREITAS, Augusto. Esboço do Código Civil. Brasília: Ministério da Justiça, Fundação Universidade de Brasília, 1983, p 10.

48 Sobre Savigny e a escola histórica do direito ver: ORESTANO, Riccardo. Introduzione allo studio del diritto romano. Torino: Giappichelli, 1963, p. 28 a 243. A escola histórica do direito entende que "come il mondo físico sarebbe retto dalla legge della causalità, così il mondo morale, sociale e
} 
DAL RI, Luciene; BENARRÓS, Myriam. Da constituição imperial ao esboço: a formação do direito brasileiro e o conceito de pessoa. Revista Eletrônica Direito e Política, Programa de Pós-Graduação Stricto Sensu em Ciência Jurídica da UNIVALI, Itajaí, v.16, n.3, 30 quadrimestre de 2021. Disponível em: www.univali.br/direitoepolitica - ISSN 1980-7791.

estudo denominado como Pandetística, realizando uma leitura das Pandectas por meio do uso da filosofia kantiana e com a aplicação de princípios jurídicos que implicam a autonomia privada, a predominância do direito subjetivo e a liberdade dos contratos, da propriedade e da livre sucessão testamentária. ${ }^{49}$

\subsection{0 conceito primitivo de pessoa e as suas modificações positivas}

Savigny desenvolve o seu trabalho em dois níveis, o primeiro de direito romano, trabalhando com conceitos e normas tipicamente antigas e outro de direito romano "hodierno", justificando assim as modificações realizadas em relação ao primeiro. ${ }^{50}$ Observa-se essa dinâmica de dois níveis por meio do conceito de pessoa, onde em um primeiro nível o autor reconhece o significado do termo como homem; e em um segundo nível o modifica por meio da aplicação da categoria de "sujeito de direito". O conceito de pessoa passa, então, a implicar a "capacidade de ter direitos", ou seja, "capacidade jurídica". ${ }^{51}$

giuridico sarebbe retto dalla legge di finalità, sicchè il fine sarebbe il vero creatore del diritto". ORESTANO, Riccardo. Introduzione allo studio storico del diritto romano. Torino: Giappichelli, 1963 , p. 235 e ss.

${ }^{49}$ Savigny nos seus escritos teria dado as idéias dominantes a serem aplicadas. LUIG, Klaus. La pandettistica come scienza guida della scienza giuridica dell'ottocento. In SCHIPANI, Sandro (Org.). Augusto Teixeira de Freitas e il Diritto Latinoamericano. Collana di studi giuridici latinoamericani "Roma e America", I. Padova: Cedam, 1988, p. 290: "Il nuovo ideale, dunque, era una organizzazione dello Stato ed un ordinamento giuridico che lasciassero libero l'individuo nel perseguire i propri fini nella società. L'individuo è libero e autônomo. L'etica, per altro, non è fuori dagli obbiettivi dello Stato, ma essa si realizza attraverso l'autonomia dell'individuo, e non è più realizzata direttamente dallo Stato. Lo Stato rende possibile il prosseguimento dell'etica, ma non la produce più. Da queste concezioni generali, derivavano i seguenti principi dell'ordinamento giuridico: il principio dell'autonomia privata; la predominanza del diritto soggettivo; la liberta dei contratti, della proprietà, e della libera successione testamentaria".

50 Observa-se, portanto, que não há um paralelismo aproximável a um exercício de direito comparado, mas uma linha de continuidade entre os dois níveis. Essa aplicação de dois níveis denota, porém, um paradoxo de continuidade e descontinuidade em relação ao direito romano, visto que, o autor mesmo realizando a modificação dos conceitos pretende o reconhecimento dentro de um quadro de referência do direito romano.

51 O conceito de "capacidade jurídica" ou é relativo apenas à possibilidade de ter direitos objetivamente no momento da relação jurídica e não equivale à capacidade de adquiri-los. SAVIGNY, Federico Carlo Di. Sistema del Diritto romano attuale, II. Tradução de Vittorio Scialoja. Torino: Unione Tipografico - Editrice, 1888, p. 1: "Ogni rapporto giuridico consiste nella relazione di una persona con un'altra persona. Il primo elemento di esso, che richiede un più minuto esame, è la natura delle persone, la reciproca relazione delle quali è capace di formare quel rapporto. Perciò qui si deve rispondere alla questione: Chi può essere soggetto di un rapporto giuridico? Questa questione 
DAL RI, Luciene; BENARRÓS, Myriam. Da constituição imperial ao esboço: a formação do direito brasileiro e o conceito de pessoa. Revista Eletrônica Direito e Política, Programa de Pós-Graduação Stricto Sensu em Ciência Jurídica da UNIVALI, Itajaí, v.16, n.3, 30 quadrimestre de 2021. Disponível em: www.univali.br/direitoepolitica - ISSN 1980-7791.

Ogni diritto esiste a causa della liberta morale insita in ciascun uomo. Perciò il concetto primitivo della persona ossia del soggetto di diritti deve coincidere col concetto dell'uomo, e questa primitiva identità dei due concetti si può esprimere con la formola seguente: Ogni singolo uomo, e solo l'uomo singolo, è capace di diritto. Tuttavia questo primitivo concetto della persona può dal diritto positivo ricevere modificazioni di due maniere, limitative ed estensive, già accennate nella formula enunciata. Può cioè, in primo luogo negarsi a taluni singoli uomini, in tutto o in parte, la capacità giuridica. Può, in secondo luogo, estendersi la capacità a qualche altro ente, oltre l'uomo singolo, e così può artificialmente formarsi una persona giuridica. 52

Com o uso dessas categorias completa-se a desnaturação do conceito de pessoa, que passa a coincidir (ou não) com o significado de homem. O conceito de pessoa, enquanto "sujeito de direito", divide-se então em duas categorias: "pessoa natural" que se refere à "capacidade jurídica natural" e "pessoa jurídica" que se refere à "capacidade jurídica artificial".

\subsection{Capacidade jurídica}

A capacidade jurídica é o elemento distintivo entre o conceito de homem e pessoa natural em Savigny, sendo pessoa natural o ser humano com possibilidade de "ter direitos" e sendo, portanto, sujeito nas relações jurídicas. Nota-se na obra de Savigny a delineação de alguns aspectos fundamentais da capacidade jurídica natural como as suas limitações (início e fim) e restrições.

As limitações à capacidade jurídica natural implicam delimitar o seu início e o seu fim. Tem-se o início da capacidade jurídica natural com o nascimento e o seu fim

è relativa alla possibilità di avere diritti, ossia alla capacità giuridica, non alla possibilita di acquistarli, ossia alla capacità di agire, della qualle tratteremo più oltre in una delle seguenti sezioni".

52 "Nella presente sezione si devono anzitutto fissare i limiti della persona intesa secondo il suo concetto primitivo o naturale, si devono poi esporre le duplici modificazioni, per le quali nel nostro diritto positivo questo concetto naturale è stato trasformato". SAVIGNY, Federico Carlo Di. Sistema del Diritto romano attuale, II. Tradução de Vittorio Scialoja. Torino: Unione Tipografico - Editrice, 1888 , p. 1 s. 
DAL RI, Luciene; BENARRÓS, Myriam. Da constituição imperial ao esboço: a formação do direito brasileiro e o conceito de pessoa. Revista Eletrônica Direito e Política, Programa de Pós-Graduação Stricto Sensu em Ciência Jurídica da UNIVALI, Itajaí, v.16, n.3, 30 quadrimestre de 2021. Disponível em: www.univali.br/direitoepolitica - ISSN 1980-7791.

com a morte. ${ }^{53}$ Entende-se por nascimento a perfeita separação do homem vivo da sua mãe, bem como a sua natureza humana. ${ }^{54}$

As restrições à capacidade jurídica são concernentes à redução ou negação imposta pelo ordenamento jurídico à capacidade de direito do homem, implicando a criação de diferentes graus de capacidade jurídica e fazendo com que alguns homens sejam incapazes de alguns ou de todos os direitos. Dentro do quadro de restrições à capacidade jurídica apresentam-se as três classificações do status personae em direito romano: liberi, servi; cives, latini e peregrini; sui iuris, alieno iuris.

Constata-se no direito romano "hodierno" diferenciações relativas às três classificações de direito romano, sendo que em contraposição à plenitude de direitos do homem livre encontra-se a incapacidade absoluta do escravo, que mesmo sendo reconhecido "originariamente" como pessoa não "teria" esse status no direito "hodierno". 55

53 Não tratar-se-a do problema de presunção de morte por ausência, visto que Savigny admite a aplicação de algumas disposições do direito consuetudinário que se distinguem do direito romano; e nem mesmo da presunção de morte simultânea.

54 Savigny preocupa-se em distinguir o nascimento aparente daquele verdadeiro. 0 verdadeiro nascimento implica em: separação da mãe; completa separação; vida do nascido depois da completa separação e natureza humana desse (à ser comprovada pela forma humana). SAVIGNY, Sistema del Diritto romano attuale, II, p. 6 . O início da capacidade jurídica tem como efeitos a anulação do testamento paterno que não considera o filho e a aquisição da herança deixada pelo pai morto em testamento. Nega-se assim ao nascituro o status de pessoa e consequentemente o exclui de qualquer direito. Esse fato, porém, não implica a negação da existência de vida antes do nascimento e justamente em defesa dessa Savigny propõe a teoria da ficcio. SAVIGNY, Federico Carlo Di. Sistema del Diritto romano attuale, II. Tradução de Vittorio Scialoja. Torino: Unione Tipografico - Editrice, 1888 , p. 11: "Il naturale principio della personalità giuridica è stato fissato nel momento della nascita completa. A questa precede però un non breve lasso di tempo, nel quale il fanciullo ha già vita, non però vita per sè stante, ma dipendente da quella della madre e con essa intimamente conessa". Ver também CATALANO, Pierangelo. Il concepito 'soggetto di diritto' secondo il sistema giuridico romano. In Procreazione assistita: problemi e prospettive. Atti del Convegno tenutosi a Roma il 31 gennaio 2005. Fasano: Schena Editore, 2005, p. $111 \mathrm{s.}$

${ }^{55} \mathrm{~A}$ análise do status do escravo torna-se hipotética, visto que, o instituto da escravidão na sociedade européia do seculo XIX é inexistente. SAVIGNY, Federico Carlo Di. Sistema del Diritto romano attuale, II. Tradução de Vittorio Scialoja. Torino: Unione Tipografico - Editrice, 1888, p. 31: "Secondo il limguaggio dei moderni giuristi dovremmo aspettarci, che agli schiavi, a causa di questa loro totale incapacità giuridica, fosse stato negato anche il nome di persona, cosicchè questa espressione fosse da considerarsi come destinata particolarmente ad indicare l'uomo capace giuridicamente". Nesse sentido a proteção jurídica dada ao escravo em favor da vida e contra os tratamentos inumanos não é uma concessão de direitos, mas sim uma limitação à sua incapacidade jurídica. No mesmo sentido é interpretada a parentela originada durante o estado de escravidão como proibição do matrimonio após a aquisição do estado de liberdade. SAVIGNY, Federico Carlo Di. 
DAL RI, Luciene; BENARRÓS, Myriam. Da constituição imperial ao esboço: a formação do direito brasileiro e o conceito de pessoa. Revista Eletrônica Direito e Política, Programa de Pós-Graduação Stricto Sensu em Ciência Jurídica da UNIVALI, Itajaí, v.16, n.3, 30 quadrimestre de 2021. Disponível em: www.univali.br/direitoepolitica - ISSN 1980-7791.

\subsection{A pessoa de existência visível e a sua "capacidade civil" em Teixeira de Freitas}

Com clara influência das ideias de Savigny encontra-se no art. 16 do Esboço para a aplicação de um conceito abstrato de pessoa, baseado na ideia de ente e condicionado à aquisição de direitos.

Art. 16: "Todos os entes suscetíveis de aquisição de direitos são pessoas".

A palavra ente realiza a extrema abstração do conceito de pessoa permitindo a sua aplicação à qualquer coisa, que possa adquirir direitos. 56 O sentido da palavra direito em Teixeira de Freitas reflete em muito aquele de Savigny, sendo estreitamente ligado ao poder e à vontade de cada pessoa, à liberdade humana politicamente regulada pelas leis. O jurista europeu reconhece esse poder de cada pessoa como direito subjetivo, observação presente no Esboço por meio do reconhecimento desse como faculdade.

(...) são direitos adquiridos, exprimindo, na frase de Savigny, o domínio da vontade livre, isto é, um poder efetivo em relação a uma pessoa, ou em relação a uma coisa. ${ }^{57}$

Sistema del Diritto romano attuale, II. Tradução de Vittorio Scialoja. Torino: Unione Tipografico - Editrice, 1888, p. 34: "La ragione di ciò stava senza dubbio nel fatto, che la parentela come impedimento al matrimonio viene considerata non già come rapporto giuridico, ma come rapporto meramente umano".

$56 \mathrm{O}$ uso da palavra ente por Teixeira de Freitas pode ser indicativa em relação à tradução francesa da obra de Savigny, visto que, Teixeira de Freitas provavelmente não conhecia o alemão. No texto original, Savigny expressa o conceito de pessoa "Person" como "Etwas", que significa algo, alguma coisa. Na tradução francesa usa-se como sinônimo de "Etwas" a palavra ente. Ver TEIXEIRA DE FREITAS, Augusto. Esboço do Código Civil. Brasília: Ministério da Justiça, Fundação Universidade de Brasília, 1983, p. 9.

57 TEIXEIRA DE FREITAS, Augusto. Esboço do Código Civil. Brasília: Ministério da Justiça, Fundação Universidade de Brasília, 1983, p. 9. Ver: SAVIGNY, Federico Carlo Di. Sistema del Diritto romano attuale, I. Tradução de Vittorio Scialoja. Torino: Unione Tipografico - Editrice, 1888, p. 36. Ver também SOUZA VIEGAS, Carlos Henrique de. O Vocabulário e o Esboço de Teixeira de Freitas. In Diritto e Storia, $n^{\circ}$ 6, 2007 (rev. eletrônica): www.dirittoestoria.it/6/Tradizione-romana/ViegasVocabulario-Esboco-Teixeira-de-Freitas.htm\# 3. \%96 Teixeira de Freitas Lexic\%f3graf . 
DAL RI, Luciene; BENARRÓS, Myriam. Da constituição imperial ao esboço: a formação do direito brasileiro e o conceito de pessoa. Revista Eletrônica Direito e Política, Programa de Pós-Graduação Stricto Sensu em Ciência Jurídica da UNIVALI, Itajaí, v.16, n.3, 30 quadrimestre de 2021. Disponível em: www.univali.br/direitoepolitica - ISSN 1980-7791.

As pessoas são reconhecidas então no comentário do Esboço como "(...)os entes predestinados para adquirir direitos com os predicados constitutivos de sua existência". ${ }^{58}$

O cerne do conceito de pessoa é apresentado sendo a aquisição de direitos, identificado positivamente, ao qual corresponde o vínculo das obrigações. O papel da pessoa é identificado então como ativa ou passivamente, em âmbito jurídico, enquanto suscetível de adquirir direitos ou criar vínculos de obrigações. As pessoas são consideradas então como elementos permanentes das relações, tendo como elemento variável os direitos e obrigações a elas concernentes. ${ }^{59}$

O papel da pessoa em âmbito jurídico é exercido por meio da "capacidade civil", enquanto instrumento que permite o exercício das relações de direito enquanto sujeito ativo ou passivo dos direitos. O conceito abstrato de pessoa, enquanto ente possuidor de "capacidade civil", permite a cisão, embora parcial no Esboço, em relação ao conceito de homem. ${ }^{60} \mathrm{O}$ conceito de pessoa passa então a abarcar duas classes $^{61}$ :

- pessoa de existência visível;

- pessoa de existência ideal;

A "capacidade civil" pode ser dividida, então, como "de direito" ou "de fato", sendo a "capacidade de direito" o grau de aptidão de cada classe de pessoas para adquirir direitos. A "capacidade civil", entendida como "suscetibilidade de adquirir direitos", enquanto base distintiva do conceito de "pessoa" é o instrumento que permite

\footnotetext{
58 TEIXEIRA DE FREITAS, Augusto. Esboço do Código Civil. Brasília: Ministério da Justiça, Fundação Universidade de Brasília, 1983, p. 9.

59 Cria-se uma relação de sujeito ativo ou passivo em relação ao direito, enquanto seu objeto. TEIXEIRA DE FREITAS, Augusto. Esboço do Código Civil. Brasília: Ministério da Justiça, Fundação Universidade de Brasília, 1983, p. 9 s.

60 O léxico de Teixeira de Freitas refaz-se em muito àquele de Savigny, sem para tanto apresentar total similitude de conceitos. Colhe-se nesse sentido, no comentário ao artigo 16 e 17 o conceito de pessoa de existência visível e ideal, assim como a motivação para o uso desses termos.

61 TEIXEIRA DE FREITAS, Augusto. Esboço do Código Civil. Brasília: Ministério da Justiça, Fundação Universidade de Brasília, 1983, p. 10, art. 17: "As pessoas, ou são de existência visível, ou de existência tão somente ideal. Elas podem adquirir os direitos, que o presente Código regula, nos casos, e pelo modo, e forma, que no mesmo se determinar. Dai dimana sua capacidade, e incapacidade civil".
} 
DAL RI, Luciene; BENARRÓS, Myriam. Da constituição imperial ao esboço: a formação do direito brasileiro e o conceito de pessoa. Revista Eletrônica Direito e Política, Programa de Pós-Graduação Stricto Sensu em Ciência Jurídica da UNIVALI, Itajaí, v.16, n.3, 30 quadrimestre de 2021. Disponível em: www.univali.br/direitoepolitica - ISSN 1980-7791.

reconhecer esse status a todos os homens incluindo: escravo, estrangeiro e nascituro. Constata-se assim que o jurista brasileiro mesmo aproximando-se às ideias de Savigny, quanto ao método de trabalho, diferencia-se no uso de conceitos, enquanto instrumentos para operar dentro de um sistema jurídico.

O autor brasileiro faz especificações especiais, explicando nos comentários a diferença de uso de conceitos.

Para este escritor (Savigny), que generalizara o Direito Romano, capacidade de direito é, e não podia deixar de ser, o caráter distintivo dos seres humanos que aquele Direito reputava pessoas, por contraposição aos que privava de personalidade. Para nós, para a civilização atual, todo homem é pessoa: pois que não há homem sem a suscetibilidade de adquirir direitos. ${ }^{62}$

A passagem acentua a diferença entre as ideias dos autores, mas também a leitura que Teixeira de Freitas faz de Savigny. O jurista brasileiro não distingue os dois níveis expostos no II volume da obra de Savigny, mas considera apenas as distorções que o autor alemão faz em relação à capacidade jurídica e de agir, contextualizando-as dentro do direito romano. Seguindo as distorções de Savigny, ele acaba por atribuir ao direito romano as ideias do autor alemão, ou seja, a diferenciação entre o conceito de homem e de pessoa, em base a categoria de "capacidade de direito". ${ }^{63}$

A equivocada concepção de pessoa em direito romano não o priva, porém, da sua concepção de "pessoa", enquanto status que abarca a todos os homens. ${ }^{64} \mathrm{O}$ jurista brasileiro ao afastar-se da leitura que Savigny faz do direito romano, em base à

62 TEIXEIRA DE FREITAS, Augusto. Esboço do Código Civil. Brasília: Ministério da Justiça, Fundação Universidade de Brasília, 1983, v. I, p 15: com. art. 21.

63 Nota-se essa concepção também em Bello ao afirmar que em Direito romano somente o homem livre era pessoa. BELLO, Andrés. Derecho romano. Caracas: Ministerio de Educacion, 1959, p. 11: "persona en el derecho civil de los romanos es solamente el hombre libre". O mesmo autor, porém, dispõe no Código civil do Chile que todos os homens são pessoas (art. 55).

64 A leitura equivocada em tema de "pessoa" é particularmente paradoxal àquela do nascituro onde o autor defende corretamente e em base ao Digesto o status de pessoa do nascituro no direito romano. Esse aspecto do nascituro torna-se fundamental para refleti-lo no "Esboço". 
DAL RI, Luciene; BENARRÓS, Myriam. Da constituição imperial ao esboço: a formação do direito brasileiro e o conceito de pessoa. Revista Eletrônica Direito e Política, Programa de Pós-Graduação Stricto Sensu em Ciência Jurídica da UNIVALI, Itajaí, v.16, n.3, 30 quadrimestre de 2021. Disponível em: www.univali.br/direitoepolitica - ISSN 1980-7791.

"capacidade jurídica", orienta-se à concepção de pessoa exposta na obra de Gaio e no Digesto.

\section{O RETORNO AO DIREITO ROMANO: GAIO E O CONCEITO DE PESSOA}

Ao diferenciar-se de Savigny o civilista utiliza inconscientemente elementos de noções típicas do direito romano clássico. Nesse, o conceito jurídico e natural "persona" equivale a homem, na sua diversidade de homem livre (cidadão ou estrangeiro), escravo e nascituro:

Gai. D. 1.5.1 "Omnes ius quo utimur vel ad personas pertinet vel ad res vel ad actiones"; (Todo o direito que usamos ou se refere às pessoas, ou às coisas, ou às ações ${ }^{65}$ )

Gai. D. 1.5.3 "Summa itaque de iure personarum divisio haec est, quod omnes homines aut liberi sunt aut servi"; (E assim a principal divisão do direito das pessoas é esta, que todos os homens ou são livres ou são servos ${ }^{66}$ )

Gai. Inst. 1.48 "Sequitur de iure personarum alia divisio. Nam quaedam personae sui iuris sunt, quaedam alieno iuri subiectae sunt" (Segue-se outra divisão a respeito do direito das pessoas. Pois umas são independentes; outras sujeitas a direito alheio ${ }^{67}$ ).

Gaio ao realizar a obra Institutiones sistematizou o ius civile, tendo como ponto central a referência à pessoa, enquanto "papel jurídico do homem" (livre ou servo). ${ }^{68}$ Nota-se também a estreita conexão entre a noção de pessoa com aquela de nascituro (qui in utero est e conceptus). A sistemática presente em Gaio

\footnotetext{
65 Ver Digesto de Justiniano. Liber Primus: Introdução ao direito romano. Tradução de Hélcio Maciel França MADEIRA. 2. edição. São Paulo: Editora Revista dos Tribunais, 2000, p. 55.

${ }^{66}$ Ver Digesto de Justiniano. Liber Primus: Introdução ao direito romano. Tradução de Hélcio Maciel França MADEIRA. $2^{\circ}$ ed. São Paulo: Editora Revista dos Tribunais, 2000, p. 55.

${ }^{67}$ CORREIA, Alexandre; SCIASCIA, Gaetano. Manual de Direito Romano. Institutas de Gaio e de Justiniano vertidas para o português. Volume II. São Paulo: Edição Saraiva, 1951, p. 31.

$68 \mathrm{O}$ conceito de pessoa enquanto homem (livre ou servo) reflete o aspecto natural do conceito jurídico. Tal fato não implica, porém, igualdade em nível normativo, porque livres e servos fazem parte de categorias diferentes.
} 
DAL RI, Luciene; BENARRÓS, Myriam. Da constituição imperial ao esboço: a formação do direito brasileiro e o conceito de pessoa. Revista Eletrônica Direito e Política, Programa de Pós-Graduação Stricto Sensu em Ciência Jurídica da UNIVALI, Itajaí, v.16, n.3, 30 quadrimestre de 2021. Disponível em: www.univali.br/direitoepolitica - ISSN 1980-7791.

também é observada no Digesto que desde o primeiro livro trata do conceito de pessoa. ${ }^{69}$

Teixeira de Freitas transcendeu assim à influência de Savigny e discordou em relação ao autor alemão por meio do retorno ao direito romano. Esse retorno baseia-se no método usado pelos juristas romanos e é bem compreendido por Teixeira Freitas, tendo como base a natureza das coisas e nesse caso a "condição geral da humanidade".

O jurista dos trópicos partindo de bases romanísticas identifica que em direito romano todos podem mudar de status e, portanto, são suscetíveis de adquirir direitos. A "suscetibilidade de adquirir direitos" somada à "condição geral de humanidade" transformaram-se nos elementos de afirmação do conceito de pessoa, abarcando todos os homens dentro do Esboço. Tal fato não implica o correto conhecimento do conceito de pessoa em direito romano, mas a consciência de mobilidade dentro daquele. ${ }^{70}$

\section{CONSIDERAÇÕES FINAIS}

A formação do direito brasileiro é perpassada pelo ideal de codificação europeu, presente desde a primeira constituição brasileira e desenvolvido no decorrer do século XIX. O processo de codificação do Direito Civil brasileiro foi, porém, tortuoso, implicando primeiramente na organização das leis vigentes portuguesas e brasileiras, por meio da Consolidação das Leis Civis e posteriormente iniciando o Esboço do Código Civil.

\footnotetext{
69 Hermogenianus, D. 1.5.2: "Cum igitur hominum causa omne ius constitutum sit, primo de personarum statu ac post de ceteris, ordinem edicti perpetui secuti et his proximos atque coniunctos applicantes titulos ut res patitur, dicemus".

70 As ideias que Teixeira Freitas tem da escravidão podem ser colhidas nos comentários aos artigos da Consolidação Ver. TEIXEIRA DE FREITAS, Augusto. Consolidação das Leis Civis. $3^{\circ}$ ed. (edição fac-simile). Brasília: Senado Federal, 2003, notas aos artigos: 42, 48, 58, 60, 96, 97,411 e 959.
} 
DAL RI, Luciene; BENARRÓS, Myriam. Da constituição imperial ao esboço: a formação do direito brasileiro e o conceito de pessoa. Revista Eletrônica Direito e Política, Programa de Pós-Graduação Stricto Sensu em Ciência Jurídica da UNIVALI, Itajaí, v.16, n.3, 30 quadrimestre de 2021. Disponível em: www.univali.br/direitoepolitica - ISSN 1980-7791.

No Esboço, Teixeira de Freitas refletiu sua formação romanista e a influência da tradição europeia, e particularmente de Savigny, no direito brasileiro. O trabalho do autor brasileiro perpassou a reinterpretação do direito romano e da pandetística, construindo soluções específicas para o ordenamento jurídico nacional. Um exemplo de reinterpretação do trabalho de Savigny, naquele de Teixeira de Freitas, é encontrado na abordagem dos conceitos de capacidade jurídica, sujeito de direito e pessoa.

Por meio da alteração do conceito de pessoa por Savigny, com a consequente extensão da "capacidade jurídica" aos "entes artificiais", completou-se a sua desvinculação da concepção de ser humano. Desvinculação que vinha sendo traçada desde o século XVI, com Donellus e Duarenus. Essa teoria encontra plena difusão com a influência da obra do autor alemão sobre a cultura jurídica e os códigos do século XIX, implicando não apenas na extensão da categoria de pessoa, mas na limitação e negação de direitos ao homem, enquanto estrangeiro, nascituro ou escravo.

A perspectiva de Teixeira de Freitas, exposta no Esboço, denota, porém, concepção diversa daquela de Savigny, na delineação dos citados conceitos jurídicos. O jurista brasileiro funda-se no jusnaturalismo, assim como no método e conteúdo aplicado pelos jurisconsultos romanos, sobre a "natureza das coisas", última razão dentro do seu discurso jurídico, identificando o caráter concreto para a formulação do direito.

Muito embora o amplo conhecimento do trabalho pandetístico, a influência de Savigny é aceita naquilo em que corresponde ao resultado do método usado por Teixeira de Freitas. A base romanística do Esboço permite ainda, com maior facilidade, a influência da obra de Teixeira de Freitas sobre outros países latinoamericanos, visto as fontes e origens da tradição ibero-americana.

\section{REFERÊNCIAS DAS FONTES CITADAS:}

AHRENS, Heinrich. Cours de droit naturel. 8 ed. Leipzig: F.A. Brockhaus, 1892. 
DAL RI, Luciene; BENARRÓS, Myriam. Da constituição imperial ao esboço: a formação do direito brasileiro e o conceito de pessoa. Revista Eletrônica Direito e Política, Programa de Pós-Graduação Stricto Sensu em Ciência Jurídica da UNIVALI, Itajaí, v.16, n.3, 30 quadrimestre de 2021. Disponível em: www.univali.br/direitoepolitica - ISSN 1980-7791.

BELLO, Andrés. Derecho romano. Caracas: Ministerio de Educacion, 1959.

CATALANO, Pierangelo. Il concepito 'soggetto di diritto' secondo il sistema giuridico romano. In Procreazione assistita: problemi e prospettive Atti del Convegno tenutosi a Roma il 31 gennaio 2005. Fasano: Schena Editore, 2005.

CORREIA, Alexandre; SCIASCIA, Gaetano. Manual de Direito Romano. Institutas de Gaio e de Justiniano vertidas para o português. Volume II. São Paulo: Edição Saraiva, 1951.

COSTA, Mário Júlio de Almeida. História do Direito Português. Coimbra: Almedina, 2012.

DA COSTA, Moacyr Lobo. Breve notícia histórica do direito processual civil brasileiro e de sua literatura. São Paulo: Revista dos Tribunais, 1970.

Digesto de Justiniano. Liber Primus: Introdução ao direito romano. Tradução de Hélcio Maciel França MADEIRA. 2. edição. São Paulo: Editora Revista dos Tribunais, 2000

ESPITIA GARZÓN, Fabio. Historia del Derecho Romano. $2^{\circ}$ ed. Bogotá: Universidad Externado de Colombia, 2006.

GUZMAN BRITO, Alejandro. Historia de la codificación civil en Iberoamérica. Santiago: Editorial Jurídica, 2006.

GUZMÁN BRITO, Alejandro. Codificación y consolidación: una comparación entre el pensamiento de A. Bello y el pensamiento de Teixeira de Freitas. In SCHIPANI. Sandro. (Org.) Augusto Teixeira de Freitas e il diritto latinoamericano. Collana di studi giuridici latinoamericani "Roma e America", I. Padova: Cedam, 1988.

LOBO, Abelardo Saraiva da Cunha. Curso de Direito Romano. Brasília: Edições do Senado Federal, vol. 78, 2006.

LUIG, Klaus. La pandettistica come scienza guida della scienza giuridica dell'ottocento. In SCHIPANI, Sandro (Org.) Augusto Teixeira de Freitas e il diritto latinoamericano. Padova: Cedam, 1988.

MEIRA, Silvio. Teixeira de Freitas. 0 jurisconsulto do Imperio. Brasilia: Cegraf, 1983.

MOREIRA ALVES, José Carlos. A formação romanística de Teixeira de Freitas e seu espírito inovador. In: Sandro (Org.). Augusto Teixeira de Freitas e il Diritto Latinoamericano. Collana di studi giuridici latinoamericani "Roma e America", I. Padova: Cedam, 1988.

ORESTANO, Riccardo. Introduzione allo studio del diritto romano. Torino: Giappichelli, 1963. 
DAL RI, Luciene; BENARRÓS, Myriam. Da constituição imperial ao esboço: a formação do direito brasileiro e o conceito de pessoa. Revista Eletrônica Direito e Política, Programa de Pós-Graduação Stricto Sensu em Ciência Jurídica da UNIVALI, Itajaí, v.16, n.3, 30 quadrimestre de 2021. Disponível em: www.univali.br/direitoepolitica - ISSN 1980-7791.

PECORELLA, Corrado. Consolidazione e codificazione in una esperienza brasiliana. In SCHIPANI. S. (Org.) Augusto Teixeira de Freitas e il diritto latinoamericano. Collana di studi giuridici latinoamericani "Roma e America", vol. 1. Padova: Cedam, 1988.

PETRONIO, Ugo. La Lotta per la codificazione. Torino: Giappichelli, 2002.

PONTES DE MIRANDA, Francisco Cavalcanti. Fontes e evolução do Direito Civil Brasileiro. Bibliotheca Scientifica Brasileira. V Collecção Economica e Juridica. Volume CCXIV. Rio de Janeiro: Pimenta de Mello, 1928.

REALE, Miguel. Humanismo e Realismo Jurídicos de Teixeira de Freitas. In: SCHIPANI, Sandro (Org.). Augusto Teixeira de Freitas e il Diritto Latinoamericano. Collana di studi giuridici latinoamericani "Roma e America", I. Padova: Cedam, 1988.

REIS, Thiago. Teixeira de Freitas leitor de Savigny. In: Interpretatio Prudentium direito romano e tradição romanista em revista. Lisboa, I, 2016.

SANTOS JUSTO, António. A influência do direito português na formação do direito brasileiro. In Revista Jurídica da FA7, Fortaleza, vol. 1, nº 1 (jan./dez.) 2004

SCHIPANI, Sandro. La codificazione del diritto romano comune. Torino: Giappichelli, 1999.

SOUZA VIEGAS, Carlos Henrique de. O Vocabulário e o Esboço de Teixeira de Freitas. In Diritto e Storia, $n^{\circ}$ 6, 2007 (rev. eletrônica): www.dirittoestoria.it/6/Tradizione-romana/Viegas-Vocabulario-Esboco-Teixeirade-Freitas.htm\#_3._\%96_Teixeira_de_Freitas_Lexic\%f3graf .

SEELAENDER, Airton L.C.L. A policia e o Rei-Legislador: Notas sobre Algumas Tendências da legislação Portuguesa no Antigo Regime. In BITTAR, Eduardo C.B. (Org.) Historia do direito brasileiro. São Paulo: Atlas.

TEIXEIRA DE FREITAS, Augusto. Consolidação das Leis Civis. $3^{\circ}$ ed. (edição fac-simile). Brasília: Senado Federal, 2003.

TEIXEIRA DE FREITAS, Augusto. Esboço do Código Civil. Brasília: Ministério da Justiça, Fundação Universidade de Brasília, 1983.

SAVIGNY, Federico Carlo Di. Sistema del Diritto romano attuale. Tradução de Vittorio Scialoja. Torino: Unione Tipografico - Editrice, 1888.

VIORA, Mario E. Consolidazione e codificazione: contributo alla storia della codificazione. $3^{\circ}$ ed. Torino: Giappichelli, 1967.

WALD, Arnold. A obra de Teixeira de Freitas e o Direito Latino-Americano. In Revista de Informação Legislativa. Brasília, a. 41 n. 163 jul/set. 2004. 
DAL RI, Luciene; BENARRÓS, Myriam. Da constituição imperial ao esboço: a formação do direito brasileiro e o conceito de pessoa. Revista Eletrônica Direito e Política, Programa de Pós-Graduação Stricto Sensu em Ciência Jurídica da UNIVALI, Itajaí, v.16, n.3, 30 quadrimestre de 2021. Disponível em: www.univali.br/direitoepolitica - ISSN 1980-7791.

WOLKMER, Antonio C. Historia do direito no Brasil. Rio de Janeiro: Forense, 1999. 